\title{
Fish communities of interacting shallow-water habitats in tropical oceanic regions*
}

\author{
James D. Parrish \\ U.S. Fish \& Wildlife Service, Hawaii Cooperative Fishery Research Unit, 2538 The Mall, University of Hawaii, Honolulu, \\ Hawaii 96822, USA
}

\begin{abstract}
Coral reefs occur in a variety of situations in the Atlantic, Pacific and Indian Oceans, which. involve great differences in the degree of isolation from surrounding shallow-water environments, e.g. seagrass beds, mangroves and unvegetated sediments. Mangroves and seagrass beds appear to offer attractive habitat for fishes - including species commonly found on reefs - especially for settling postlarvae and developing juveniles. These habitats probably intercept large numbers of recruits, and may offer some advantages over coral reefs for early survival of young juveniles. They may act as accumulators of excess recruits, which could tend to smooth out the temporal patchiness of recruits available to reefs directly from the plankton. However, there is no clear evidence that, in general, reefs situated favorably to the shallow-water, vegetated habitats experience enhancement of these early life stages, by comparison with more remote reefs. There are a few demonstrated mechanisms for movement of plant and animal material (alive, dead or reprocessed) between these shallow-water habitats, including recycling of reef organic production through an adjacent habitat and back to the reef. The absolute values of such fluxes assimilated by (or returned to) the reef may be small, but the means by which the material is exchanged may be particularly suitable to enhance fish populations. Relative trophic patterns among the various shallow-water, demersal habitats and among the oceans of the world are not entirely clear. This is partly because quantitative fish community studies and trophic studies in seagrass and mangrove habitats are inadequate. Among fish, camivores appear to dominate in all habitats in almost all situations; usually benthic invertebrates are the major prey group. In a few reported situations, primarily in the Pacific, planktivory appears to be the dominant feeding mode. Algivory is important in all situations, but almost never dominant, and its importance varies widely within (as well as between) oceans and types of situations. It may be most significant on the open coasts of some isolated islands and atolls. Seagrass is a minor direct food source in all oceans and is best documented in the Atlantic. If important linkages occur among the shallow-water, adjacent, tropical habitats, they most likely involve fish recruitment and/or trophic processes involving invertebrates. Both are little-known subjects in these environments, that will require additional, focused research to clarify the nature and magnitude of any interactions that influence marine resources
\end{abstract}

\section{INTRODUCTION}

Coral reefs occur widely in the tropical Atlantic, Pacific and Indian oceans, in a wide variety of situations. They are often adjacent to extensive seagrass beds and mangrove tracts that provide very different habitats for biota. Both these latter habitats have high

\footnotetext{
- This review originates from a UNESCO/COMAR workshop held in Fiji comparing Atlantic and Pacific tropical coastal ecosystems
}

primary productivity, with much export as dissolved or detrital organic material fOdum et al. 1959, Bakus 1969, Heald \& Odum 1970, Odum \& Heald 1972, 1975. Buesa 1974, McRoy \& McMillan 1977, Ogden 1980 , Cintron \& Schaeffer-Novelli 1983, Rodelli et al. 1984, Robertson et al, in press). Both types of habitat provide suitable protective cover for many species of marine fish and invertebrates. It has long been suspected that there may be important ecological linkages between these diverse habitats in terms of flux of energy or materials, obligate use of a combination of the habitats 
in the life cycles of animals, or other interactions (Odum \& Heald 1975, Ogden \& Zieman 1977, Ogden \& Gladfelter 1983, Birkeland 1985). It has been suggested that the functioning of such linkages largely explains the persistence of extraordinarily high densities of biomass concentrated on the limited bottom area of reefs (Bardach 1959, Starck \& Davis 1966).

Munro (1984) and Munro \& Williams (1985) have recently suggested a theoretical potential world harvest from all coral reefs of 9 million tons $\mathrm{yr}^{-1}$, much of which is fish. Thus, there are important economic as well as scientific motivations to determine how the various shallow-water tropical habitats are used by fishes, and how their ecological interactions affect productivity of 'reef' fish populations. There are undoubtedly important physical interactions, chemical exchanges, and interactions between invertebrate animals among the major shallow-water habitats (Ogden \& Gladfelter 1983, Birkeland 1985). However, I will discuss only processes that involve fish production more or less directly, assessing the characteristics and extent of the processes in the various types of situations and oceanic regions where reefs occur.

\section{FLUX OF MATERIALS AND ENERGY}

\section{Detrital drifit}

Reefs produce large quantities of detrital material (Glynn 1973, Johannes \& Gerber 1974, Gerber \& Marshall 1974a, Hobson \& Chess 1978, Hatcher 1982a). Shallow-water surroundings of almost any kind offer some opportunity for storage of such material leaving the reef. Some reef-associated fishes that forage in the water column feed heavily on it as it is washed from the reef, and thus return to the reef a portion of the potential detrital loss (Johannes 1967, Gerber \& Marshall $1974 \mathrm{a}, \mathrm{b}$, Hobson \& Chess 1978). Much of the detrital biomass appears to be benthic algae, which represents reef primary production.

Such algal 'planktivory' has been best documented in Pacific oceanic atolls (specitically Enewetak). These atolls lie in oligotrophic waters (Sargent \& Austin 1949, Odum \& Odum 1955, Taniguchi 1972) without the benefit of shallow-water surroundings lother than their lagoons). It is widely believed that they are among the most 'closed' of marine ecosystems - i.e. they are organized for maximum retention and recycling of resources. Thus, it seems adaptive that this form of recycling of reef algal primary production should be most highly developed in such situations. Appropriate studies to assess such algal 'planktivory' have apparently not been done in other situations. Its importance is beginning to be recognized, however (e.g. Williams \& Hatcher 1983).
Reef debris that is not captured by planktivores will tend to settle and accumulate in shallow-water surroundings such as seagrass beds and mangroves. Debris deposited in these habitats may return to the reef by several mechanisms. Foraging fish, commuting from the reef, may eat it directly, but diet studies of resident reef fishes do not suggest that this is a major mechanism (e.g. Randall 1967)

Reef detritus may (1) be consumed directly in these surrounding habitats by a variety of resident invertebrates, or (2) it may sustain a microflora of detritivores which is consumed by these invertebrates, or (3) if reduced to basic nutrients, it may support plant growth within the habitat. In habitats such as seagrass beds and mangroves, the food web within the habitat may produce an abundant invertebrate fauna $1 \mathrm{O}^{\prime}$ Gower \& Wacasey 1967, Heald \& Odum 1970, Austin \& Austin 1971, Abele 1974, Thomassin 1974, Brook 1975 Table 16, Heck 1977, Weinstein \& Heck 1979, Wahbeh 1982).

\section{Transport to reefs from surrounding shallows}

Fish are probably the main agent for returning to the reef this production derived from reef debris. Direct herbivory by fishes in surrounding areas is probably quantitatively important wherever reefs and vegetated habitats occur together. Seagrass and the algae within grass beds and mangrove habitats (particularly algae epiphytic on grass blades and submerged prop roots) provide important food sources for herbivores (Bakus 1969, Rutzler 1969, Austin 1971, Earle 1972, Ogden 1980, Lobel \& Ogden 1981, Harmelin-Vivien 1983).

The flux of benthic invertebrates from surrounding habitats to the reef is produced primarily by the activities of a guild of daily commuters that shelter on or near the reef by day and forage the surrounding habitats by night. The abundant apogonids and holocentrids (especially the Holocentrinae) probably fill this role to some extent in all oceans (Randall 1963, 1967, Starck \& Davis 1966, Vivien \& Peyrot-Clausade 1974, Ogden \& Zieman 1977, Weinstein \& Heck 1979). Many snapper species are moderately abundant commuting predators in all oceans (Hiatt \& Strasburg 1960 , Starck \& Davis 1966, Randall 1967, Starck 1971, Ogden \& Zieman 1977, Weinstein \& Heck 1979). Mullids also fill this role to some extent (Randall 1967. Hobson 1973 Jones \& Chase 1975, Ogden \& Zieman 1977. Weinstein. \& Heck 1979). Mullids are much more speciose and abundant in the Indo-Pacific.

Other important reef fish families with species that commute to adjacent habitats to feed on invertebrates in some parts of the Atlantic include the Sciaenidae and Muraenidae (e.g. Hobson 1975, Weinstein \& Heck 
1979), and especially the Haemulidae (Starck \& Davis 1966, Randall 1967. Starck 1971, Ogden \& Zieman 1977. McFarland 1979, Weinstein \& Heck 1979). The size and conspicuous appearance and behavior of haemulids, by comparison with more cryptic species such as holocentrids, may lead to overestimation of their abundance and importance. However, in the western Atlantic, they are unquestionably very important as transport agents from the surroundings to the reef in terms of abundance, diet, great foraging range, and dependence on the reef surroundings for food.

Throughout much of the Pacific and Indian oceans, which lack haemulid commuters, the Lethrinidae apparently fill a somewhat similar role (Hiatt \& Strasburg 1960, Talbot 1960, Jones \& Chase 1975). They are nowhere as abundant as the largest concentrations of haemulids, and they do not occur on western Atlantic reefs. Many less abundant reef species also forage the invertebrate fauna of grass beds, e.g. Serranidae (Randall 1963, Harmelin-Vivien \& Bouchon 1976), Scorpaenidae (Starck \& Davis 1966, Harmelin-Vivien \& Bouchon 1976), Fistulariidae (Weinstein \& Heck 1979), and Aulostomidae (Weinstein \& Heck 1979). Meyer et al. (1983) listed 15 families with species that 'feed away from and then rest in or over coral heads'.

The diel cycle of carnivorous feeding may vary considerably between regions. In the Caribbean, there are significant influxes to the grass beds of nocturnal predators on benthic invertebrates. At Tulear, Madagascar (Harmelin-Vivien 1983), the nocturnal predators on invertebrates are almost entirely planktivores, and most predators on benthic invertebrates are diurnally active (and probably more nearly resident).

\section{Disposition of imported material}

Material brought to the reef by commuting fish is incorporated into the rcef trophic system through a number of mechanisms. Since the commuters are reef residents, food input from the surroundings represents support of reef biomass. Commuting fish are also consumed by resident piscivores, e.g. serranids, lutjanids, muraenids and synodontids. In studies of community piscivory in the Northwestern Hawailan Islands, Apogonidae comprised $15 \%$ of all fish prey individuals, Mullidae $9 \%$, and Holocentridae $4 \%$ (Norris \& Parrish in press). Similarly, Caribbean Haemulidae are major prey for resident snappers and other piscivores (Starck \& Davis 1966, Randall 1967). In all areas studied, the wide ranging, demersal commuters appear to be a major staple in the diets of resident piscivores (Hiatt \& Strasburg 1960, Talbot 1960, Randall 1967).

Of all food consumed by carnivorous commuter fishes, up to $20 \%$ may be lost by defecation and excre- tion (Mann 1969). A good deal of unassimilated food is voided on the reef. Recycling can occur by direct coprophagy. Coprophagy by fish has frequently been casually observed and has recently been studied and quantified in some detail (Robertson 1982). There is every reason to believe that this practice is widespread and that it may recycle a significant fraction of the food imported but not directly assimilated. Although data are lacking, it seems likely that much of the feces voided by fish is eaten by reef invertebrates and thus recycled on the reef. All benthic community studies show large populations of invertebrates that seem likely scavengers of fish feces. Most of these detritivores can feed effectively in the interstices of the reef substrate where feces often settles. After some time on the reef surface, feces may become nutritionally enriched by accumulated microflora.

The potentially important effects of imported fish excretory products on sessile reef invertebrates (particularly corals) have recently been investigated (Meyer et al. 1983, Nelson 1985). Measurements showed elevated levels of dissolved nutrients in the water column and increased sedimentary feces on the bottom in the vicinity of large schools of haemulid commuters loitering on the reef after a night's feeding. Comparison of growth measurements of adjacent corals against controls, and experimental removal of a fish school from a coral gave somewhat ambiguous results, but suggested that increased coral growth from this fertilization process may be measurable where commuters are concentrated. Whether measurable by present methods or not, the mechanism is entirely credible and probably operates widely on reefs. Such effects of fertilization on benthic algae would be expected to occur widely also

\section{Importance and geographic distribution of transport processes}

These relatively small components of the total flux between productive shallow-water habitats may be disproportionately important for several reasons. Oceanic inputs of energy to reefs are often very low. Thus, even small direct fluxes from surrounding habitats are possibly important. To a large extent, reefs appear to maintain their high biomass and rate of productivity by internal recycling. Thus, they are probably well adapted to enhance their trophic budgets by recycling through these spatially and temporally short loops. The surrounding habitats in which some of these fluxes originate are highly productive, both at the primary level and at the level of benthic invertebrate forage animals (e.g. Rodriguez 1959, O'Gower \& Wacasey 1967. Rutzler 1969, Heald \& Odum 1970, Austin \& 
Austin 1971, Thomassin 1974, Brook 1975 Table 16, Heck 1977. Wahbeh 1982). For several of the mechanisms described, import to the reef occurs at trophic levels that are close to direct support of fish populations, so the trophic efficiency is high. Even the import of inorganic nutrients (e.g. as completely reduced excreta) fertilizes benthic algae, much of which is consumed directly by fish on the reef.

The types of trophic transfers described are limited almost entirely to situations in which reefs are adjacent to extensive shallows. For atolls and small, high islands surrounded by steep slopes, adjacent shallow-water habitats are limited. Much of the reef in the central Pacific occurs in such situations, with little or no seagrass or mangrove present. Thus, the mechanisms for trophic exchange and reproductive interaction (discussed below) among shallow habitats are less important in these regions. In large portions of the western Atlantic, bathymetry and the occurrence of extensive vegetated, shallow-water habitats favor such interactions. Important fish commuters occur in abundance, and focused research has produced direct evidence of trophic exchanges. In other oceanic regions where bathymetry and surrounding habitats are favorable, there appears to have been less focused study and little direct evidence. A major, diumally conspicuous commuter family (the Haemulidae) is missing, and the most abundant predators that are likely to fill the role have cryptic diurnal habits, and thus have been poorly assessed in all oceanic areas. It seems established that commuter fish foraging in habitats surrounding reefs is an important trophic transfer mechanism in the Caribbean. A basically similar mechanism exists in generally similar areas of the Pacific and Indian oceans; it is not clear whether it is as important quantitatively.

\section{MOVEMENT BETWEEN NURSERY AND ADULT HABITATS}

\section{Function of surrounding areas as nurseries for reef fish}

The young of almost all reef species go through pelagic stages. It is not clear how effectively the postlarvae of any particular reef tract may be returned to it by ocean circulatory processes and behavioral adaptations (Johannes 1978, Munro \& Williams 1985, Lobel \& Robinson 1986). However, whatever the parental source of larvae, it is not evident that all reefs receive an abundant supply (Williams 1980, Leis 1982, Doherty 1982, 1983, Victor 1983, Munro \& Williams 1985, Sale 1985. Walsh 1987). Many reefs are of very limited area and not favorably situated to receive abundant recruits. If reefs are prime habitat for many species (as seems to be the case), but a limited and difficult 'target' for planktonic larvae to hit, then a strategy of settling nearby in a suitable nursery habitat and migrating to the reef later as a nektonic adult or subadult would seem adaptive for the individual. Such a nursery or 'waiting room' would insure an adequate supply of recruits for reef populations. Even in reef situations where pelagic recruits are normally superabundant, this 'waiting room' would serve as a buffer to maintain recruitment during occasional poor years.

The shallow surroundings of reefs have the potential to serve the accumulator/buffer function. They are often extensive, typically much more so than the reef, and more or less continuous over a considerable linear extent. For example, mangroves may occupy many continuous miles. These areas are often at or near a shoreline, where arriving planktonic larvae are more likely to be retained. As a net result, such areas may effectively intercept and maintain planktonic young that miss the reef directly. Where sampling has been done for recruits in the general vicinity of reefs, they appear to be present and to recruit to any suitable substrate as well as to the reef (Russell et al. 1977 , Eckert 1985, Sale 1985, Schroeder 1985). Habitats such as grass beds and mangroves should attract and sustain settling recruits that they intercept.

These nursery habitats may offer improved survival in contrast to settlement directly on the reef. On reefs, predation is believed to be particularly intense, especially on very young fish (Johannes 1978, Doherty \& Sale 1985, Norris 1985). Norris \& Parrish (in press) found some fish parts in the gut contents of 52 fish species from a total of 126 examined from Northwestern Hawaiian Islands reefs. Most prey were juveniles. There is generally a lower total density of adult fish in grass beds, mangroves, and other surrounding habitats (Ogden \& Zieman 1977, Blaber 1980, 1986). Some active, abundant reef piscivores are absent or greatly reduced in numbers there. Large piscivorous predators forage in these habitats, but they may produce a net positive effect on survival of young recruits by controlling the local abundance of moderate size piscivores (Ogden \& Zieman 1977. Ogden 1980). Seagrass (even. artificial grass) has been shown experimentally to provide protective concealment for small and medium size macrocrustaceans (Main 1987), and it is apparently similarly effective for small fish (Winn \& Bardach 1960, Randall 1965, Ogden \& Zieman 1977, Ogden 1980).

There is probably a range of sizes after first settlement during which surrounding habitats such as grass beds and mangroves provide attractive shelter with improved survival. As the fish grow, reefs apparently become more attractive for most species. The resulting community composition in the various habitats has been widely observed (Austin 1971, Brook 1975, 
Weinstein \& Heck 1979, Ogden 1980, Blaber 1980 1986, Martin \& Cooper 1981). Since the material and energy for maintenance and growth from settlement size to the size at migration is supplied largely from the surrounding nursery habitats, the movement of a relatively small biomass of maturing fish to the reef represents a large subsidy.

\section{Observational evidence about nurseries for reef fishes}

A good number of young 'reef' fish are in fact found in these surrounding habitats. The data are difficult for several reasons. Relatively few quantitative assessments of whole fish communities seem to have been attempted in tropical seagrass beds and very few in mangroves. Logistical problems of sampling quantitatively close among mangroves are severe, and studies in those habitats tend to be not well quantified. Assessments were not all made near coral reefs, and the proximity to reefs was not always reported.

\section{Mangroves \\ Indo-Pacific}

Quinn \& Kojis (1985) in Papua New Guinea made a direct, qualitative comparison of the fish fauna in a mangrove site near coral reefs and in a site remote from reefs, and detected little difference. They reviewed the few and sketchy available reports from the Papua New Guinea area and the study by Blaber (1980) in northeastern Australia. Based on these sources, they reported that the evidence did not suggest that the proximity of coral reefs significantly altered estuarine (mangrove) fish assemblages in the region, and that the mangrove areas studied served as nurseries for very few species of reef fish. However, Blaber (1980) collected a number of species that appear to be reefrelated in the mangrove estuary at Cairns (several kilometers from reef tracts on the Great Barrier Reef). Their greater abundance in the mangrove estuary than in the open bay, together with the opposite trend in distribution of their adult predators, led Blaber to conclude that the mangrove provided an effective nursery. Collections by Blaber (1986) in mangroves of the Dampier region of northwest Australia also contained the young of a number of species that appear to be reefrelated in some localities. The proximity to reefs in this study is not clear.

Results of Lal et al. (1984) in Fiji indicated a high incidence of reef-related species among the fishes in their mangrove collections. They concluded that the mangrove tract studied was important both as a nursery and feeding ground for a number of species from the nearby coastal reefs. Talbot (1960) reported that juveniles of several important species of lutjanids of the reefs off Tanzania, East Africa were abundant in mangroves of the area.

\section{Western Atlantic}

Austin (1971) and Austin \& Austin (1971) reported that mangroves in western Puerto Rico harbored the juveniles of a number of fishes common to the nearby reefs. They believed that the mangroves provided an important nursery for reefs in the area. Odum \& Heald (1972) extensively collected the fishes of estuarine mangroves in the North River, inland of Cape Sable in south Florida. The site is at some distance from extensive coral development, but several reef-associated species were collected (some commonly or abundantly).

\section{Seagrass beds}

Indo-Pacific

Harmelin-Vivien (1983) made extensive collections of the fish communities in various grass bed habitats at the great reef at Tulear, Madagascar. She reported an abundance of juvenile fishes of many common groups of reef residents and commented on the major nursery role provided by the grass beds. Based on extensive underwater visual census work in a variety of habitats in Cocos Lagoon, Guam, Jones \& Chase (1975) recorded large numbers of juveniles of several important reef fishes in grass beds. They concluded that the lagoon was an invaluable nursery for many of the species', largely due to the 'natural cover available'.

\section{Western Atlantic}

Ogden \& Zieman (1977) made estimates of the considerable density of juveniles of some of the species that inhabit seagrass beds at St Croix, US Virgin Islands and also occur (some prominently) in the adult fauna of neighboring reefs. At St Croix, McFarland (1979) and Brothers \& McFarland (1981) specifically studied the settlement of postlarval haemulids to grass bed nurseries, followed by later recruitment of the matured juveniles to coral patch reefs.

In Thalassia and Syringodium grass beds near mangrove shores in southwestern Puerto Rico, Cooper (1974) and Martin \& Cooper (1981) consistently found many fish species common to the neighboring coral reefs. They also reported that the fish community com- 
position was demonstrably different in pure stands of these 2 different seagrasses. Brook $(1975,1977)$ made collections of whole fish communities throughout the year in seagrass beds among the coral keys just off the southeast coast of Florida. His collections contained a high percentage of juvenile fishes, many of which were reef-associated species, and seasonal influxes of juveniles were recorded. Weinstein \& Heck (1979) attempted to collect the entire fish communities in seagrass beds in Caribbean coastal waters of Panama. All sites were apparently in the general vicinity of coral reefs, and 2 sites were specifically selected for their proximity to mangroves and coral reefs respectively. The authors reported that the faunas of all 4 sites contained about the same species, and that all had much in common with reef faunas (much more so than did seagrass faunas sampled in the northern Gulf of Mexico, remote from reefs). They concluded that the Panama grass beds act as an important nursery for reef fish, and that many fishes treat reefs and grass beds as a single habitat.

\section{Global and regional interpretations}

There remains to be demonstrated quantitatively the extent to which fishery yields from reefs are a function of surrounding shallow-water nursery habitats. Some of the evidence cited above suggests such a relationship, and there are other supporting qualitative observations. Ogden \& Gladfelter (1983) pointed out that seagrass beds and mangrove regions are often excellent fishing grounds for larger (reef-related) predatory fishes. They concluded that the predators thrive on juvenile fish and invertebrates that have outgrown the protection of these habitats, In some cases (e.g. Heald \& Odum 1970, Rodelli et al. 1984), some major trophic pathways have been identified, estimates of flux at some points in the web have been made, and the existence and value of an apparently related fishery have been cited. However, problems remain in establishing and quantifying the direct link with the fishery, particularly for reef fisheries. Based on an examination of fishery yields from various types of coral reef situations and their shallow surroundings, Marshall (1985) stated that 'no suggestion can be offered as to the possible influence of mangroves', and that 'the interaction of reef to adjacent shallows may not be as important as past interpretations have implied' Clearly there is a need for more focused comparative studies of the appropriate situations, and more direct, quantitative measurements of transfers between habitats in terms of specific high level trophic linkages, population. size and life history parameters, and movements of fishes at the cohort or population level.

In an oceanic regional perspective, strong recruit- ment and nursery interactions among the various habitats would be expected in some areas of the western Atlantic with extensive adjacent shallow-water habitats, and there are reports to suggest that some occur. There is less information for other regions, but there is no reason to expect less interaction (particularly in the western Pacific and Indian oceans) wherever suitable physical conditions and habitats occur.

Trophic or reproductive fluxes from surrounding shallows to reefs provide the reef ecosystem with some net gain in resources of materials and energy, as compared to an isolated reef system. However, there is an additional benefit from use of a resource in short supply on reefs - space. Reefs are typically crowded biotopes where competition for space can be intense. Regardless of the source of reproductive propagules or the food resource that young or adult fish consume, the fact that these activities of fish, that are currently or ultimately reef residents, can occur outside the reef, permits a higher standing crop of biomass and a more complex reef community with a higher level of total activity.

\section{COMMUNITY COMPOSITION AND TROPHIC RELATIONSHIPS}

\section{Faunal structure of communities}

The richness of the fish fauna is very different in various oceanic regions where coral reefs occur, e.g.: about 520 species in the western Atlantic (Starck 1968, Goldman \& Talbot 1976), at least 300 species in the eastern Pacific (Hobson 1968 based on Walker 1960), about 450 in Hawaii, 600 to 700 in the Marshall and Marianas Islands, at least 1500 to 2000 in areas of the Philippines, New Guinea and tropical Australia, and 700 to 900 in islands of the Indian Ocean (Seychelles and Madagascar) (Goldman \& Talbot 1976). A similar trend is seen when only those species that can clearly be called coral reef fishes of individual large reef tracts are compared: about 400 species in the Florida Keys, 850 in the Capricorn group of the Great Barrier Reef, about 250 at Tutia reef off Tanzania (Starck 1968, Goldman \& Talbot 1976). The effects of these large differences in species richness must be evident at some smaller scales as well. The great majority of families, but not species, are represented in all the major oceanic regions, and there are many cognate species pairs between the regions.

The great variability in composition of fish assemblages in different microhabitats of any reef makes it difficult to define or quantify the community for an entire reef tract (Williams 1982, Williams \& Hatcher 1983, Russ 1984a). Therefore, few rigorous quantitative comparisons have been attempted on large geographic 
scales (e.g. oceanic regions), and the results are of little value for understanding the factors that control any differences among regions or major habitats.

Bohnsack \& Talbot (1980) found essentially the same total number of families and species attracted to similar artificial reefs in the Florida Keys and at One Tree Island, Great Barrier Reef. Comparing 20 chemically collected samples from natural reefs in the Bahamas with 20 similar samples from reefs in the Society Islands, Smith (1978) found no significant difference between the mean number of individuals in a community. The numbers of species, genera and families were significantly higher in the Bahamas. Sale (1980) examined the species richness (as a function of size of the collection) and found no significant differences between 20 patch reefs at One Tree Island and patch reefs at 13 Caribbean sites. Talbot \& Gilbert (1982) compared species richness and number of individuals and weight of the total community for 4 locations [Solomon Islands, Lizard Island (GBR), One Tree Island, and Lord Howe Island] widely separated in latitude, at about the same longitude in the western Pacific. Relatively few statistically significant differences were found except for Lord Howe Island. Similar comparisons (except weight of individuals not tested) between Lizard Island and Tutia Reef, Tanzania showed no significant differences. Sale (1980) failed to find any significant latitudinal component of variability in species richness for several coral reef communities tested. However, he found species richness negatively correlated with the distance from the Philippine Islands (his assumed zoogeographical area of faunal origin).

These comparisons fail to evaluate 'between-habitat' diversity or overall diversity of reef tracts. In almost all cases, variability appears to be high within the data from each locale. Sample sizes in most cases may be too small to permit assessing the variability at a locale adequately. Based on many samples taken across the Great Barrier Reef, Williams \& Hatcher (1983) warned that valid comparisons among widely separated regions can only be made after data is available on the range of variation within each region'. In light of these difficulties, conclusions regarding oceanic regional or habitat trends must be viewed cautiously.

\section{Community trophic structure}

Trophic structure seems a useful characteristic for comparing fish communities of oceanic regions. Results were found from 12 studies of reefs in which the community composition was well quantified and the trophic position of all components could be reasonably well assigned by the original investigator or the present author (Table 1).

\section{Herbivory}

Endosymbiotic algae, particularly the zooxanthellae of scleractinian corals, provide an algal food source inseparable from animal tissue. Some workers have approached this problem by lumping all herbivores and coral feeders together (Goldman \& Talbot 1976; see Table 1). Some fishes (e.g. scarids) may in fact acquire significant nutrition directly from the algal symbionts in animal tissue. However, in the present discussion, trophic classification and interpretation are based on the host animal as prey. Some fishes also consume plants by gleaning drift algae (covered elsewhere in this discussion) and by feeding directly on seagrasses and attached benthic algae.

\section{Seagrass feeding}

Among the categories of Table 1, seagrass feeders are perhaps most nearly 'large croppers' feeding external to the reef. Seagrass herbivory has seldom been considered as part of the trophic scheme in quantitative studies of reef fish communities. Available information is mostly scattered and anecdotal. In the two studies that considered seagrasses in a community trophic perspective (Table2), a rather small fraction of all species ate seagrass at all, and very few species ate it regularly or as a large part of the diet.

The frequent consumers that used the reef as a primary residence were apparently all scarids and acanthurids in both the West Indies and Madagascar. These species were among the diurnal (usually short-range) commuters from nocturnal reef refuges to algal or seagrass grazing grounds (Winn \& Bardach 1960, Randall 1965, Earle 1972, Ogden 1976, Ogden \& Zieman 1977, Weinstein \& Heck 1979, Alheit 1982). Some species of several other families ate more than trivial quantities of seagrass: Sparidae, Monacanthidae, Tetraodontidae, Ostraciidae, Balistidae, and Hemiramphidae. At least traces of seagrass have been found in gut contents of some species of Gerreidae, Cynoglossidae, Polynemidae and Kyphosidae (Randall 1965, 1967, Austin \& Austin 1971, Carr \& Adams 1973, Ogden 1980, Harmelin-Vivien 1983).

Seagrass feeding has been most actively studied in the western Atlantic, where conspicuous 'halos' of heavily grazed seagrasses often surround reefs within grass beds in some localities (Randall 1963, 1965, Ogden et al. 1973, Ogden 1976, Ogden \& Zieman 1977. Tribble 1981). The quantities of seagrass consumed by fishes in some western Atlantic locations are substantial (Ogden 1980, Tribble 1981, Hay et al. 1983). This activity results in a considerable effect on seagrass stands and a significant trophic transfer to reef habitats. Attempts to measure the linkage between the primary 


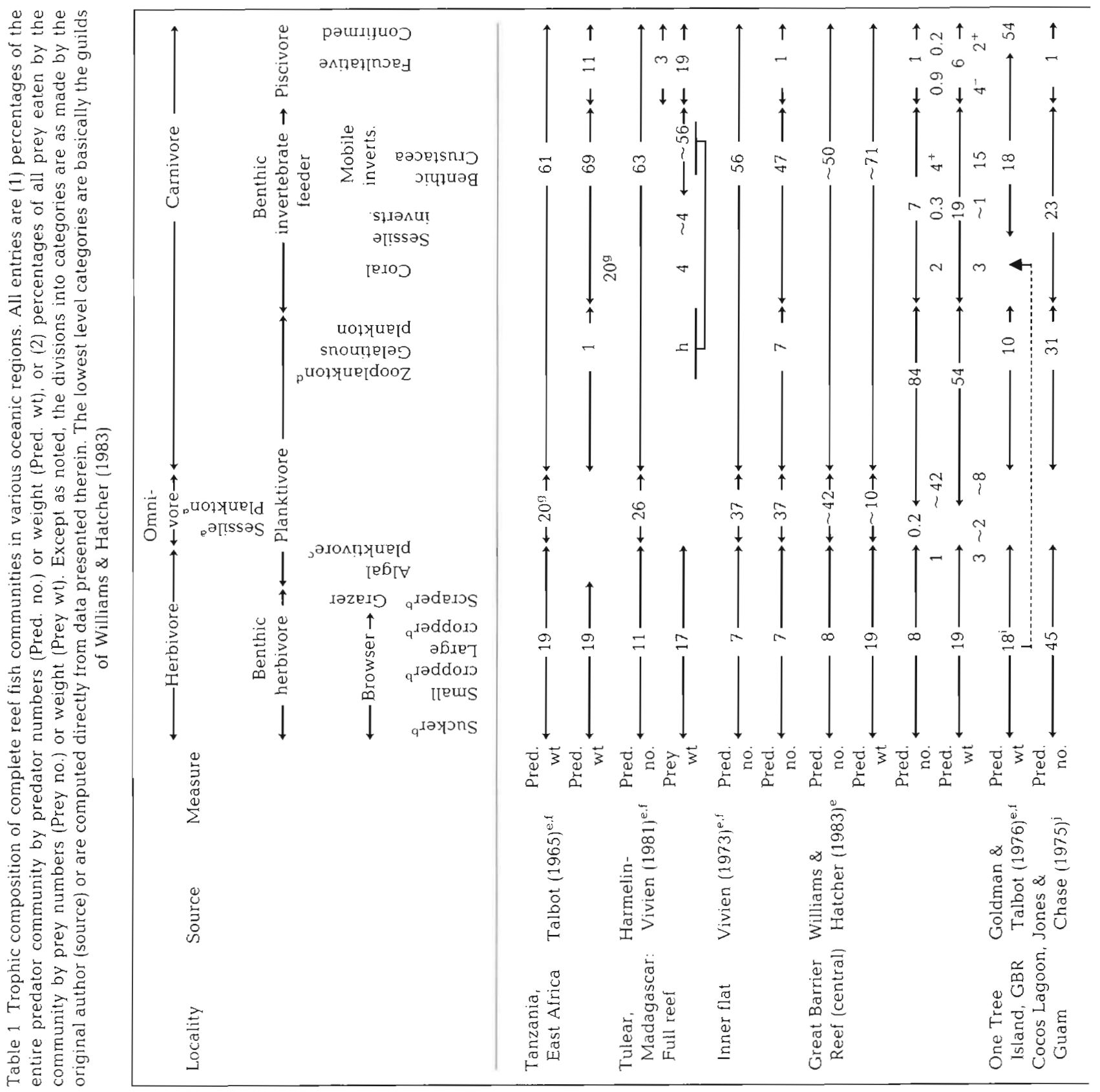

production of seagrasses and the nutrition of reef fish have produced ambiguous results (Weinstein et al. 1982), although the existence of a linkage is implied by the similarity of stable isotope ratios in fish and seagrass tissues (Fry et al. 1982).

There has been little work on quantification of seagrass grazing in other oceanic regions, and some ecologists have come to view seagrass feeding by fishes as a Caribbean phenomenon (Kikuchi \& Peres 1977, Ogden 1980). However, halos and high estimated rates of consumption have been observed at artificial reefs in a Guam grass bed (P. D. Gates pers. comm. 1987). Also, the results of Harmelin-Vivien (1983)
(Table 2) in Madagascar suggest that the general level of activity there may be of about the same order as indicated by diets of West Indian fishes. In general, it seems likely that seagrass feeding is somewhat more intense in the Caribbean than in other regions. However, more results are needed in other regions from localities with abundant grass beds.

\section{Algal feeding}

Algivores represent an important trophic component of all reef fish communities and of most shallow sur- 


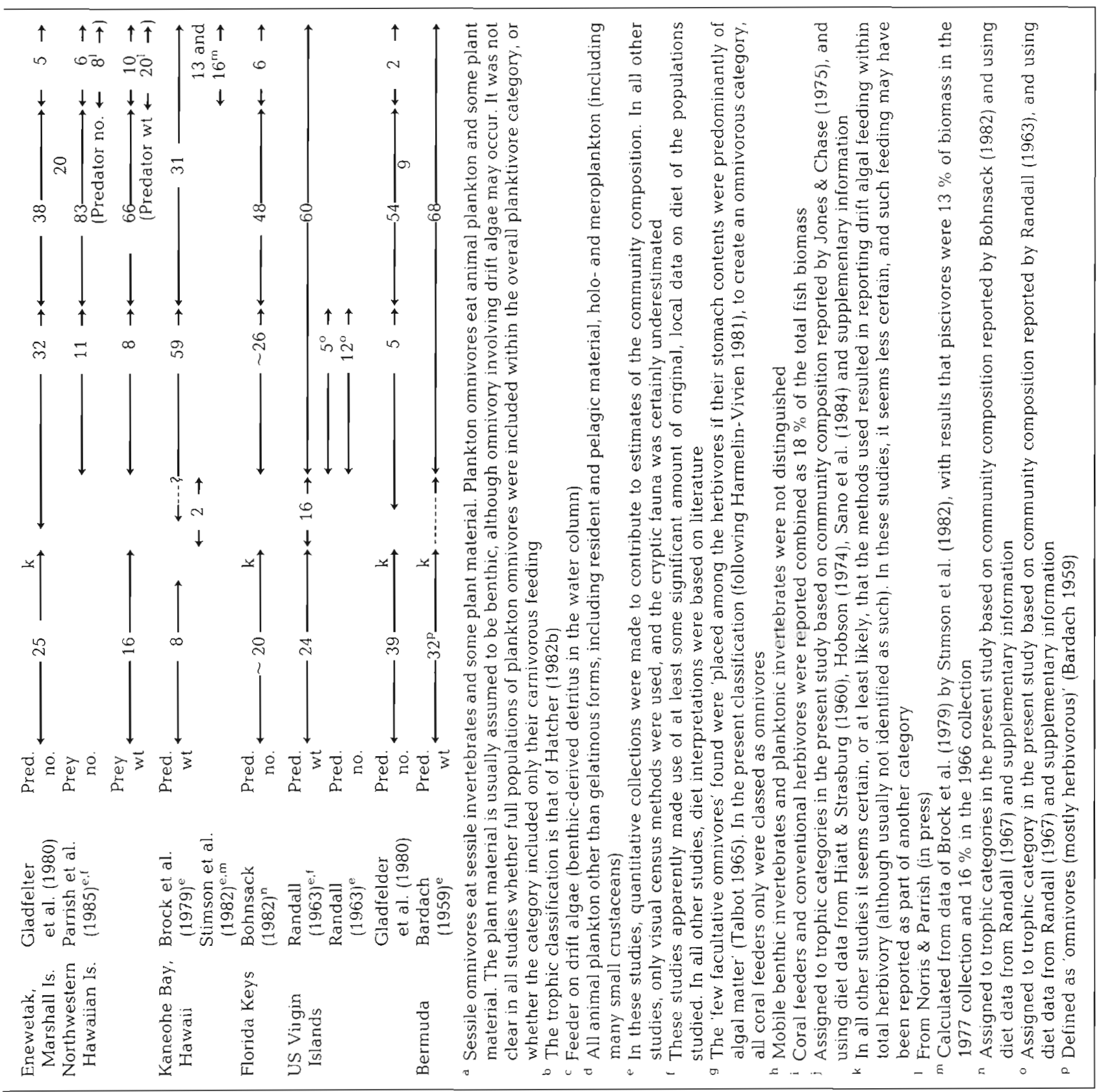

rounding areas. A large fraction of all reef herbivores in all oceanic regions are Acanthuridae or Scaridae (Bouchon-Navaro \& Harmelin-Vivien 1981). In the western Atlantic, there are very few acanthurid species, but they are extremely abundant and widespread, and all appear to be almost entirely herbivorous. In the Indo-Pacific, the family is much more speciose. Populations of several acanthurid species commonly occur and feed with a variety of specializations on diverse algal groups (Jones 1968, Robertson et al. 1979, Hatcher 1982a, Williams \& Hatcher 1983, Russ 1984a). A few Indo-Pacific acanthurids have also adopted other trophic roles, e.g. zooplanktivory (Jones 1968, Hobson 1974).

There are several common scarid species in the Atlantic, and even more in the Indo-Pacific. In reef habitats in all oceanic regions, most scarids remove algae (usually short, fine forms) very close to the substrate, and often scrape the substrate surface, ingesting carbonate material and sometimes the endolithic algae of corals (Bardach 1961, Stephenson \& Searles 1960, Randall 1965, 1967, Glynn et al. 1972, Hobson 1974).

Observers have the impression that scraping of coral and other carbonate substrates by benthic algal grazers 
Table 2. Summary of direct herbivory by fishes on seagrasses in the Virgin Islands and Tulear, Madagascar (Modified from Tables VI and VII of Harmelin-Vivien 1983)

\begin{tabular}{|c|c|c|}
\hline & \multicolumn{2}{|c|}{ Location } \\
\hline & $\begin{array}{l}\text { U.S. Virgin } \\
\text { Islands }{ }^{a}\end{array}$ & Tulear, Madagascarb \\
\hline Number of species studied & 212 & 142 \\
\hline Number (and \%) of species that contained seagrass in guts & $\begin{array}{l}32 \\
(15 \%)\end{array}$ & $\begin{array}{l}14 \\
(10 \%)\end{array}$ \\
\hline Number (and \%) of species that ate seagrasses regularly & $\begin{array}{c}4 \\
(1.9 \%)\end{array}$ & $\begin{array}{c}2 \\
(1.4 \%)\end{array}$ \\
\hline$\%$ of diet composed of seagrass for regular seagrass eaters & $\begin{array}{l}45-88 \% \\
\text { by volume }\end{array}$ & $\begin{array}{l}54-78 \% \\
\text { by weight }\end{array}$ \\
\hline$\%$ of diet composed of seagrass for all other seagrass eaters & $\begin{array}{l}0.1-17 \% \\
\text { by volume }\end{array}$ & $\begin{array}{l}0.1-5.5 \% \\
\text { by weight }\end{array}$ \\
\hline \multicolumn{3}{|l|}{ Seagrass as $\%$ of total food consumed by the fish community } \\
\hline Barrier reef grass beds ${ }^{c}$ & - & $\begin{array}{l}1.9 \% \\
\text { by weight }\end{array}$ \\
\hline Neighboring littoral grass beds ${ }^{c}$ & - & $\begin{array}{c}2.4 \% \\
\text { by weight }\end{array}$ \\
\hline $\begin{array}{l}\text { From Randall }(1967) \\
\text { From Harmelin-Vivien (1979) } \\
\text { Specimens for gut analysis were all collected from grass beds } \mathrm{i}\end{array}$ & the Great $\mathrm{R}$ & \\
\hline
\end{tabular}

is more common and intensive in the Indo-Pacific than in the Caribbean (Bakus 1964, 1967, 1969, Randall 1974, Goldman \& Talbot 1976, Sammarco 1985). However, the comparative data of Bouchon-Navaro \& Harmelin-Vivien (1981) suggest that scarids constitute a higher percentage of herbivores on Atlantic island reefs, and that acanthurids tend to be dominant on Indo-Pacific islands. More recent data from Hawaii (Hayes et al. 1982), the Florida Keys (Bohnsack 1982), the Philippines (Russ 1984b), and the Australian Great Barrier Reef (Russ 1984a) show some indication of a similar trend. Bakus $(1967,1969)$ observed the prevalence on tropical oceanic islands/atolls of the IndoPacific of mass movements of algal grazers on and off reef flats with the tide and believed that such feeding was less pronounced in the Caribbean

Significant algivory is also practiced by more stationary (usually territorial) benthic fishes, especially Pomacentrids, in all oceanic regions. The diverse and speciose pomacentrids include herbivores, planktivores and omnivores (Hiatt \& Strasburg 1960, Randall 1967, Hobson 1974, Gerber \& Marshall 1974a, Hobson \& Chess 1978, Sano et al. 1984). Diet data for many pomacentrids is scarce, and their full trophic role is often uncertain. Robertson et al. (1979) cited the results in support of the idea that algivorous pomacentrids in the Caribbean hold a relatively more important place in the total herbivorous activity than in at least some Indo-Pacific localities. The Blenniidae are perhaps the only other herbivorous family that individually makes a major quantitative contribu- tion to community herbivory everywhere, feeding primarily on short, filamentous algae. Their abundance (and herbivory) are poorly quantified in almost all localities, but it seems likely that they are of comparable importance on reefs in all oceanic regions and situations.

Many other reef-related species practice herbivory. Of 212 West Indian species analyzed for diet (Randall 1967), 59 species from 16 families contained some plant material (more than 125 species of algae and 4 kinds of marine vascular plants). The aggregate effect of the many lesser algal consumers is probably considerable in all fish communities.

The algivores as a group have been estimated for a number of locations (Bouchon-Navaro \& HarmelinVivien 1981; see Table 1). Density values are extremely variable both within and between localities. A range from at least $7 \%$ to nearly $40 \%$ of the community by numbers is found, and a nearly equal range by weight. Some isolated oceanic islands of the Indo-Pacific show a very large herbivorous component (Odum \& Odum 1955, Hobson 1974, Jones \& Chase 1975, Robertson et al. 1979, Hayes et al. 1982), but it is not clear whether there are any real overall differences between any of the major oceanic regions.

\section{Planktivory}

Pelagic planktivores. In all shallow tropical environments, there are significant numbers of planktivorous 
fish that are surface or midwater pelagics. They include species of the Clupeidae, Atherinidae, Engraulidae, Hemiramphidae, and small carangids (scads). These are all small-to-medium schooling species, which inhabit the water column and move rather indifferently over various benthic habitats. They are likely supported primarily by pelagic productivity, and will not be considered further in the discussion of fish communities relative to benthic habitats

Types of resident planktivory. What is usually considered as planktivory in tropical shallow-water systems involves at least 3 types of food resources. One form is detrital drift (discussed above), which originates at many trophic levels. It is probably best to consider fish that feed on this drift material as e.g. algivores (see above) or coral feeders, based on the composition and source of the detrital drift, regardless of where or in what condition the food material is collected. When all species that feed in the water column are-instead lumped trophically as 'planktivores', serious inaccuracies in trophic interpretation can result. For example, of 16 zooplanktivores studied by Hobson \& Chess (1978) at Enewetak, 6 species contained more than $20 \%$ drift algae ( 3 had more than $60 \%$ ).

A second major type of plankton is pelagic holoplankton, which has its origin and habitat in the water column, and to a large extent represents an import to the shallow-water habitats from surrounding waters. This plankton usually contains many copepods and other groups of small, pelagic crustaceans, as well as edible gelatinous forms (Emery 1968, Tranter \& George 1972, Johannes \& Gerber 1974, Hobson \& Chess 1978, Williams \& Hatcher 1983). For small, isolated, oceanic islands without surrounding shallows (e.g. atolls), this plankton must be the major external food resource available to reefs

The importance of 'resident' or 'demersal' meroplankton is being increasingly recognized (Gilmartin 1958, Emery 1968, Tranter \& George 1972, Johannes \& Gerber 1974, Sale et al. 1976, Alldredge \& King 1977. Porter \& Porter 1977, Hobson \& Chess 1978, Walter et al. 1982, Ohlhorst 1982). This category includes not only pelagic juvenile forms, but all other planktonic animals that are either in the plankton only briefly or that have a benthic habit during part of the day. This meroplankton is more or less resident within the shallows and is retained and probably nourished by processes different from those affecting the holoplankton (Sale et al. 1976).

Observations of several investigators (Emery 1968, Alldredge \& King 1977, Porter et al. 1977, Hobson \& Chess 1978) suggest that the high relief topography of the reef contributes to maintaining high populations of this resident plankton. It can also be found in conspicuous abundance and concentrations in seagrass beds (Emery 1968) and apparently in mangroves (Steven 1961, Tundisi 1969, Blaber 1980), where it is also eaten by fish. There appears to be no information about flux of 'resident' plankton between shallowwater habitats. This plankton is dependent to a considerable degree on resources from the reef or surrounding shallows, e.g. space, source of propagules, and likely some level of primary productivity. Bottomrelated groups such as mysids, cumaceans, amphipods, polychaetes, and crustacean larvae are much more important than in the pelagic holoplankton (Emery 1968, Sale et al. 1976, Alldredge \& King 1977. Hobson \& Chess 1978).

Some collections suggest that 'resident' plankton may be more diverse and abundant than pelagic holoplankton at and near reefs, even at an atoll and in other rather isolated reef situations (Gilmartin 1958, Bakus 1964, Sale et al. 1976, Alldredge \& King 1977). The data are probably inadequate to permit generalization about the relative importance of these types of plankton. It would be of great interest to know whether 'resident' plankton are more important on reefs associated with continents, larger islands, and extensive shallows than in small, isolated, oceanic reefs (e.g, atolls). Such a finding seems likely a priori. If it applies broadly, and if the resident plankton have short enough generation times and fast enough growth, this plankton might provide an effective mechanism for prolonging the effects of irregular and infrequent nutrient pulses resulting from events such as heavy storm run-off (Birkeland 1984, 1985). Such a mechanism could capture some of the nutrients, convert them to a form usable by higher trophic levels, and maintain the productivity locally, avoiding the loss of all the nutrients by advection or diffusion.

Regional interpretations. One major difference between Atlantic and Pacific reefs that may apply rather generally is the greater importance of zooplanktivores on Pacific reefs (Table 1). There are considerably more planktivorous species in the Indo-Pacific, both within the families that are planktivorous in the Atlantic and in other families (e.g. the Lutjanidae, Serranidae and Caesionidae). Planktivores appear to be important in the Pacific around extended or densely aggregated reef groups with extensive shallows (e.g. Williams \& Hatcher 1983, Russ 1984b, 1985) as well as on some isolated, oceanic islands/atolls (e.g. Brock et al. 1979, Gladfelter et al. 1980). However, useful comparative studies are few, and not all results fit this pattern (e.g. Hayes et al. 1982, Parrish et al. 1985). The few Atlantic results include both island and continental habitats and show lower planktivore abundance. The pattern in the Indian Ocean is less clear, but planktivory is probably less prominent than in most of the Pacific areas reported. 


\section{Omnivory}

A fair number of species in all habitats and regions eat both plant and animal material in substantial amounts. Species of the Pomacentridae, Chaetodontidae, Balistidae, Monacanthidae, and Tetraodontidae can be locally abundant, but omnivores do not commonly occur in the extreme abundances seen for algivores and planktivores. In the studies reviewed, 1.5 to over $40 \%$ of predator individuals were classed as omnivores (Table 1). The omnivorous category is inherently imprecise, and its use may obscure substantial portions of the total herbivory and carnivory occurring in a community. The abundance of omnivores does not appear to be helpful for comparing oceanic regions.

In a number of reported studies, all carnivory is lumped, or only plankton is separated from other diet categories. Where separate carnivorous subcategories are reported, more meaningful interpretations can be made regarding their sources in shallow-water habitats

\section{Piscivory}

Community studies in which piscivory could be isolated or estimated have been recently reviewed by Norris \& Parrish (in press). The range of values for piscivores as a fraction of the community is considerable: 1 to $8 \%$ by number and about 6 to $54 \%$ by biomass (Table 1). Some of the highest and lowest (and some intermediate) values come from the Australian Great Barrier Reef. There are also some moderately high values from coastal areas near large land masses in the western Indian Ocean and from smaller, isolated, oceanic islands in the central Pacific. The 2 studies from the Atlantic both lack direct diet data. One is from a small, fairly isolated, oceanic island and the other from a continental area. Their results are mixed.

The composition of piscivore taxa is strikingly different in some of the areas studied, without producing a discernible effect on the total piscivorous component. For example, groupers and snappers provide a major contribution to the piscivorous component in all oceans, except in the Hawaiian archipelago. However, values from 2 widely separated localities in Hawail are not greatly different from the estimate for Enewetak, nor lower than results from other regions.

Abundance of piscivorous fishes is particularly subject to the influence of human exploitation, since piscivores are often prized catches. Most of the studies considered here were conducted in localities exposed to relatively little fishing, and the level of fishing does not appear to bear any consistent relationship to the abundance of piscivores. For example, the localities with the greatest and the smallest piscivorous biomass component were both nearly pristine
The results for piscivory suggest some tentative generalizations. Either there are grave problems with sampling by the various methods (a not unlikely possibility for this trophic group), or some communities have a drastically different trophic structure at the top levels. On the other hand, despite obvious sampling problems, some widely scattered and otherwise disparate habitats are not dramatically different at the piscivore level. Trends related to the habitat situation are not detectable (but not excluded). It seems likely that the piscivorous component is greater in the Indo-Pacific, but good, quantitative studies which include diet data and involve unexploited communities are lacking in the Atlantic.

\section{Feeding on benthic invertebrates}

Feeding upon corals makes use of a significant food resource occurring on the reef, and may be altogether less dependent on the surroundings than most other feeding modes. Where fewer external sources of food are available, reef fish would be expected to evolve toward increased coral feeding. The data available suggest that coral feeding is indeed relatively intense in isolated reef situations with high coral cover (Randall 1974, Reese 1977). Higher coral consumption in the Indo-Pacific than in the Atlantic appears to be a common observation (Hiatt \& Strasburg 1960, Randall 1967 1974, Bakus 1969, Goldman \& Talbot 1976. Neudecker 1977). This difference is discernible even on opposite sides of the isthmus of Panama (Glynn et al. 1972, Bakus 1975), and despite the fact that the eastern Pacific coastal region has high nutrient inputs and a relatively low abundance of corals. Corallivory has not been well quantified in reports on trophics at the community level. It has occasionally been reported lumped with herbivory (e.g. Goldman \& Talbot 1976) and is often lumped with feeding on other benthic prey by carnivores or omnivores

The most abundant coral feeding fishes are certainly the Chaetodontidae, Pomacentridae, Labridae and Scaridae (Randall 1974). The Chaetodontidae include many more species for which coral is a major food source, and they are abundant enough to represent a significant trophic component (Reese 1977. HarmelinVivien \& Bouchon-Navaro 1982, 1983). Only a few pomacentrid and labrid species are involved, and the total trophic effect may be minor. A small fraction of all scarid species have been documented as eating live coral (Randall 1974). However, since scarids are abundant, active grazers on reefs, the effects could be trophically significant. Several plectognath fishes eat coral skeleton and soft tissue together, especially the Balistidae, Monacanthidae, Tetraodontidae (including Canthigasteridae) and Diodontidae (Randall 1974). 
Sessile invertebrates other than corals are especially abundant on reefs, but they are also common on mangrove prop roots, on patches of hard substrate or rubble, in seagrass beds, and even in open sand flats (Rodriguez 1959, Rutzler 1969, Parish \& Zimmerman 1977, Vacelet \& Vasseur 1977). Apparently a relatively small portion of the fish fauna anywhere has evolved effective specializations to thwart their structural, chemical and cryptic defenses and feed heavily on them (Randall 1967, Randall \& Hartman 1968, Bakus 1969, Goldman \& Talbot 1976, Neudecker 1985). Bakus (1969) concluded that fish feeding on sessile benthos was probably less intensive in the Atlantic than in the Indo-Pacific, and that Atlantic species had evolved more structural and chemical defenses in response, in contrast to the use of cryptic habits in the Indo-Pacific Vasseur (1977) recorded a similar predominance of cryptic forms among the sessile fauna in Madagascar (Indian Ocean), but he believed that the effect of fish predation was not as evident there as in the Pacific (Vacelet \& Vasseur 1977). The sparse observational data suggest that sessile invertebrate feeding is a more important trophic mode in isolated, oceanic reef areas and particularly in the Indo-Pacific

The extent of fish feeding on mobile invertebrates is highly variable among prey taxa. Echinoids are patchily distributed on an oceanic regional basis. They are eaten by a small portion of the fish fauna as a minor, but not insignificant prey. It seems probable that they are a larger portion of the diet in the Atlantic than in the Indo-Pacific because of their abundant occurrence in almost all localities and in a variety of habitats throughout the region

In almost all community trophic studies, the benthic invertebrates as a whole are the most important single trophic category (Table 1). The leading prey are usually from such groups as the crabs, shrimps, stomatopods, gastropods and polychaetes, which appear to be common in all habitats worldwide. For whole fish communities, there appear to be no data for making quantitative trophic distinctions among regions or habitats for these individual groups.

\section{DIRECTIONS FOR RESEARCH}

The processes and mechanisms proposed here for interactions among shallow-water, tropical, marine habitats are all credible, and some have been confirmed qualitatively. However, important quantitative ecological questions remain, e.g.: Where and under what circumstances does a particular interaction produce significant, perceptible effects, and what are they? Are there measurably higher standing stocks of fish or higher rates of production by fish (1) in a situa- tion where the proximity of a mangrove tract results in a large net flux of detrital material to a reef? (2) in a situation where reef resident fish commute to an adjacent grass bed and consume large quantities of secondary and higher level production that is supported by the primary production of the grass bed? (3) in a situation where many fish larvae settle in a nearby grass bed or mangrove, develop there, and subsequently migrate to the reef? If so, which groups have the life history and trophic characteristics that are favored by these neighboring resources so that their abundance or production in the reef fish community is more enhanced? Such questions as these require that research be focused in new directions.

The recent research on haemulids in the Caribbean (cited above) is perhaps the first focused effort to quantify input to the reef from surrounding habitats by foraging commuters. The results suggest that commuter feeding in that situation for that family produces measurable import to the reef. A necessary step now is to identify and assess all the quantitatively important commuters in several localities and situations, identifying their feeding grounds and diel cycles and quantifying the sizes of commuting populations and their diets. Such a study would allow an estimate of transfer between the habitats. This assessment should include herbivores and the nocturnally active, diurnally cryptic (and usually abundant) species such as the Holocentridae and Apogonidae. In different regions and situations, different commuters (and perhaps different prey) may be important, and this may produce a detectable overall effect on the entire community.

Feeding by fishes within grass beds in the tropical environs of reefs has been little studied. Most studies to date were either (1) from the subtropics, (2) from areas remote from reefs, or (3) where multiple habitats were available, feeding from the grass beds was not identifiable or separable. It would be particularly useful to know specifically what flora and fauna from grass beds contribute to the support of reef based commuters and grass bed residents, particularly the temporary juvenile fish residents.

Particular emphasis should be given to investigating situations outside the better-studied Caribbean. The results may indicate that qualitatively different things are happening in different regions. If so, a likely cause would be a difference in the occurrence of the key fauna. If all the faunal components that appear to be appropriate were present but simply not performing the same functions, the result could lead to some further interesting ecological studies to determine why structurally similar but functionally different systems have evolved in the different regions.

The evidence available to date for the proposed nursery function of surrounding habitats for juvenile 
fish consists largely of the occurrence in the surrounding habitats of juveniles of species that occur as adults on reefs. Establishing a direct relationship between juveniles in the nursery and adults in the final habitat will not be easy. Possible approaches might include well-controlled, long-term body marking experiments (e.g. using coded wire or miniature visual implant tags), use of radioactive tracers or stable isotope analysis where diets in the habitats appear significantly different, or examination of microstructure patterns deposited in hard parts (e.g. otoliths), particularly in the earliest stages near settlement. It would clearly be valuable to demonstrate for even a small number of cases that this recruitment interaction mechanism does or does not function in a quantitatively significant way.

It should also be fruitful to seek direct observational evidence of the effects of proximity of different habitat types. Sites would be selected as similar as possible in all other respects, but differing in the types of habitats occurring together, e.g.: reefs with and without grass beds, mangroves, and any other available combinations of common, shallow-water habitats. Variables measured and compared between sites would be the relative abundance of fish species, total population density of the fish community, quantitative species composition, stability of the abundance and community composition over a period of several years, trophic composition, and fish production.

With well-chosen sites and adequate sample sizes, the results might strongly suggest that certain cooccurring habitats do or do not interact so as to affect fish populations in one or both habitat(s). That indication alone would have major ecological and resource habitat management implications. Furthermore, the nature of any differences would likely give clues as to the mechanisms responsible. For example, relative species abundances might be different for known commuting foragers or for species known to use a surrounding habitat as juveniles. A difference in temporal stability observed over several years might well indicate the functioning of a surrounding habitat as an accumulator of recruits.

Field experiments such as removals of commuters or juveniles, blocking of commuting or migration paths, or reduction of shelter or food resources offer prospects for focusing on the effective mechanisms. Any of these experiments could simply be applied to selected habitats initially. However, the experimental program would likely be more efficient and better directed after the proposed initial paired comparisons of natural situations. When (and if) some particular mechanisms of interaction. have been demonstrated and studied within an environment (e.g. an oceanic region), it should be profitable to look for these mechanisms in similar situations in other regions. If regional differences emerge, it should then be possible to identify them specifically at the level of the mechanism and associate such differences with the effects at the population and community levels.

This full line of inquiry will certainly be long, difficult and complex. It deals with some basic questions in marine ecology, involving complex interactions of individually complex systems. For exactly these reasons it is also of great importance to theoretical and applied ecology, and its resolution will be of great value to the management of habitats and living resources. Fortunately, the first important steps in this line of research involve modest cost, time and effort and can produce very useful results.

Acknowledgements. I appreciate the financial support of UNESCO and the leadership of C. E. Birkeland and J. R. E. Harger in organizing and leading the UNESCO/COMAR workshop which provided the opportunity to develop these ideas for discussion with other tropical marine ecologists. An earlier, more extensive version of this review was printed by UNESCO (Parrish 1987)

\section{LITERATURE CITED}

Abele, L. G. (1974). Species diversity of decapod crustaceans in marine habitats. Ecology 55: 156-161

Alheit, J. (1982). Feeding interactions between coral reef fishes and the zoobenthos. Proc. 4 th Int. Coral Reef Symp. 2: $545-552$

Alldredge, A. L., King, J. M. (1977). Distribution, abundance, and substrate preferences of demersal reef zooplankton at Lizard Island Lagoon, Great Barrier Reef. Mar Biol. 41 . 317-333

Austin, H. M. (1971). A survey of the ichthyofauna of the mangroves of western Puerto Rico during December, 1967-August, 1968. Caribb. J. Sci. 11. 27-39

Austin, H., Austin, S. (1971). The feeding habits of some juvenile marine fishes from the mangroves in western Puerto Rico. Caribb. J. Sci. 11: 171-178

Bakus, G. J. (1.964). The effects of fish-grazing on invertebrate evolution in shallow tropical waters. Occ. Pap. Allan Hancock Fdn 27, p. 1-29

Bakus, G. J. (1967). The feeding habits of fishes and primary production at Eniwetok, Marshall Islands. Micronesica 3: 135-149

Bakus, G. J. (1969). Energetics and feeding in shallow marine waters. Int. Rev. gen exp. Zool. 4: 275-369

Bakus, G. J. (1975). Marine zonation and ecology at Cocos Island, off Central America. Atoll Res. Bull. 179: 1-9

Bardach, J. E. (1959). The summer standing crop of fish on a shallow Bermuda reef. Limnol. Oceanogr. 4: 77-85

Bardach, J. E. 11961). Transport of calcareous fragments by reef fishes. Science 133: 98-99

Birkeland, C. (1984). Influence of topography of nearby land masses in combination with local water movement patterns on the nature of nearshore marine communties. In: Productivity and processes in island marine ecosystems. UNESCO Reports Marine Science 27, p. 16-31

Birkeland, C. (1985). Ecological interactions between mangroves, seagrass beds, and coral reefs. United Nations Environment Programme Regional Seas Reports and Studies No. 73: 1-26 
Blaber, S. J. M. (1980). Fish of the Trinity Inlet system of North Queensland with notes on the ecology of fish fauna of tropical Indo-Pacific estuaries. Aust. J. mar. Freshwat. Res. 31: $137-146$

Blaber, S. J. M. (1986). Feeding selectivity of a guild of piscivorous fish in mangrove areas of north-west Australia. Aust. J. mar. Freshwat. Res. 37-329-336

Bohnsack, J. A. (1982). Effects of piscivorous predator removal on coral reef fish community structure. In: Cailliet, G. M., Simenstad, C. A. (eds.) GUTSHOP 81: Fish food habits studies. Proceedings 3rd Pacific Workshop. Washington Sea Grant Publication. University Washington, Seattle, p. $258-267$

Bohnsack, J. A., Talbot, F. H. (1980). Species packing by reef fishes on Australian and Caribbean reefs: an experimental approach. Bull. mar. Sci. 30: 710-723

Bouchon-Navaro, Y., Harmelin-Vivien, M. L. (1981). Quantitative distribution of herbivorous reef fishes in the Gulf of Aqaba (Red Sea). Mar. Biol. 63: 79-86

Brock, R. E., Lewis, C., Wass, R. C. (1979). Stability and structure of a fish community on a coral patch reef in Hawaii. Mar. Biol. 54: 281-292

Brook, I. M. (1975). Some aspects of the trophic relationships among the higher consumers in a seagrass community (Thalassia testudinum Konig) in Card Sound, Florida. Ph. D. thesis, University of Miami, Coral Gables

Brook, 1. M. (1977). Trophic relationships in a seagrass community (Thalassia testudinum), in Card Sound, Florida Fish diets in relation to macrobenthic and cryptic faunal abundance. Trans. Am. Fish. Soc. 106: 219-229

Brothers, E. B. McFarland, W N. (1981). Correlations between otolith microstructure, growth, and life history transitions in newly recruited French grunts (Haemulon flavolineatum [Desmarest], Haemulidae). Rapp. P.-v. Réun. Cons. int. Explor. Mer 178: 369-374

Buesa, R. J. (1974). Population and biological data on turtle grass (Thalassia testudinum Konig, 1805) on the Northwestern Cuban shelf. Aquaculture 4: 207-226

Carr, W. E. S., Adams, C. A. (1973). Food habits of juvenile marine fishes occupying seagrass beds in the estuarine zone near Crystal River, Florida. Trans. Am. Fish. Soc. 102 $511-540$

Cintron, G., Schaeffer-Novelli, Y (1983). Mangrove forests: ecology and response to natural and man induced stressors. In: Ogden, J. C., Gladfelter, E. H. (eds.) Coral reefs seagrass beds and mangroves: their interaction in the coastal zones of the Caribbean. UNESCO Reports Marine Science 23, p. 87-113

Cooper, M. (1974). A survey and comparison of the fish fauna found in two common species of tropical Atlantic sea grasses. M. S. thesis, University of Puerto Rico, Mayaguez

Doherty, P. J. (1982). Coral reef fishes: recruitment-limited assemblages? Proc. 4th Int. Coral Reef Symp. 2: 465-470

Doherty, P. J. (1983). Tropical territorial damselfishes: Is density limited by aggression or recruitment? Ecology 64:176-190

Doherty, P. J., Sale, P. F. (1985). Predation on juvenile coral reef fishes: an exclusion experiment. Coral Reefs 4: 225-234

Earle, S. A. (1972). The influence of herbivores on the marine plants of Great Lameshur Bay, with an annotated list of plants. In: Collette, B. B., Earle, S. A. (eds.) Results of the Tektite Program: ecology of coral reef fishes. Natural History Museum Los Angeles County Science Bulletin 14 p. $17-44$

Eckert, G. J. (1985). Settlement of coral reef fishes to different natural substrata and at different depths. Proc. 5th Int. Coral Reef Congr 5: 385-390
Emery, A. R. (1968). Preliminary observations on coral reef plankton. Limnol. Oceanogr 13: 293-303

Fry, B., Lutes, R., Northam, M., Parker, P. L., Ogden, J. (1982) $\mathrm{A}^{13} \mathrm{C} /{ }^{12} \mathrm{C}$ comparison of food webs in Caribbean seagrass meadows and coral reefs. Aquat. Bot. 14: 389-398

Gerber, R. P., Marshall, N. (1974a). Ingestion of detritus by the lagoon pelagic community at Eniwetok Atoll. Limnol Oceanogr 19: 815-825

Gerber, R., Marshall, N. (1974b). Reef pseudoplankton in lagoon trophic systems. Proc. 2nd Int. Coral Reef Symp. 1 105-107

Gilmartin, M. (1958). Some observations on the lagoon plankton of Eniwetok Atoll. Pacif. Sci. 12: 313-316

Gladfelter, W. B., Ogden, J. C., Gladfelter, E. H. (1980). Similarity and diversity among coral reef fish communities: a comparison between tropical western Atlantic (Virgin Islands) and tropical central Pacific (Marshall Islands) patch reefs. Ecology 61: 1156-1168

Glynn, P. W. (1973). Ecology of a Caribbean coral reef. The Porites reef-flat biotope: Part II. Plankton community with evidence for depletion. Mar. Biol. 22: 1-21

Glynn, P. W., Stewart, R. H., McCosker, J. E. (1972). Pacific coral reefs of Panama: structure, distribution and predators. Geol. Rundsch. 61: 483-519

Goldman, B., Talbot, F. H. (1976). Aspects of the ecology of coral reef fishes. In: Jones, O. A., Endean, R. (eds.) Biology and geology of coral reefs. Vol. 3, Biology No. 2. Academic Press, New York, p. 125-154

Harmelin-Vivien, M. L. (1979). Ichtyofaune des recifs coralliens de Tulear (Madagascar): ecologie et relations trophiques. These de Doctorat es-Sciences, Univ. Aix-Marseille II

Harmelin-Vivien, M. L. (1981). Trophic relationships of reef fishes in Tulear (Madagascar). Oceanologica Acta 4: 365-374

Harmelin-Vivien, M. L. (1983). Etude comparative de l'ichtyofaune des herbiers de phanerogames marines en milieux tropical et tempéré. Rev. Ecol. Terre Vie 38: 179-210

Harmelin-Vivien, M. L., Bouchon, C. (1976). Feeding behavior of some carnivorous fishes (Serranidae and Scorpaenidae) from Tulear (Madagascar). Mar. Biol. 37: 329-340

Harmelin-Vivien, M. L., Bouchon-Navaro, Y (1982). Trophic relationships among chaetodontid fishes in the Gulf of Aqaba (Red Sea). Proc. 4th Int. Coral Reef Symp. 2: $537-544$

Harmelin-Vivien, M. L., Bouchon-Navaro, Y (1983). Feeding diets and significance of coral feeding among chaetodontid fishes in Moorea (French Polynesia). Coral Reefs 2 $119-127$

Hatcher, B. G. (1982a). The interaction between grazing organisms and the epilithic algal community of a coral reef: a quantitative assessment. Proc. 4th Int. Coral Reef Symp. 2: 515-524

Hatcher, B. G. (1982b). Grazing on coral reef ecosystems. In: Barnes, D. J. (ed.) Perspectives on coral reefs. Brian Clouston Publisher, Manuka, Australia (for Australian Institute of Marine Science), p. 164-179

Hay, M. E., Colburn, T., Downing, D. (1983). Spatial and temporal patterns in herbivory on a Caribbean fringing reef: the effects on plant distribution. Oecologia (Berl.) 58: 299-308

Hayes, T. A., Hourigan, T F., Jazwinski, S. C., Jr., Johnson, S. R., Parrish, J. D., Walsh, D. J. (1982). The coastal resources, fisheries and fishery ecology of Puako, West Hawaii. Hawaii Cooperative Fishery Research Unit Technical Report 82-1. $159 \mathrm{p}$.

Heald, E. J., Odum, W. E. (1970). The contribution of man- 
grove swamps to Florida fisheries. Proc. Gulf Caribb. Fish Inst. 22: $130-135$

Heck, K. L., Jr. (1977). Comparative species richness, composition, and abundance of invertebrates in Caribbean seagrass (Thalassia testudinum) meadows (Panama). Mar. Biol. 41: 335-348

Hiatt, R. W., Strasburg, D. W. (1960). Ecological relationships of the fish fauna on coral reefs of the Marshall Islands. Ecol. Monogr. 30: 65-127

Hobson, E. S. (1968). Predatory behavior of some shore fishes in the Gulf of California. U.S. Fish Wildl. Serv. Res. Rep. 73, p. 1-92

Hobson, E. S. (1973). Diel feeding migrations in tropical reef fishes. Helgoländer wiss. Meeresunters. 24: 361-370

Hobson, E. S. (1974). Feeding relationships of teleostean fishes on coral reefs in Kona, Hawaii. Fish. Bull. U.S. 72: 915-1031

Hobson, E. S. (1975). Feeding patterns among tropical reef fishes. Am. Scient. 63: 382-392

Hobson, E. S., Chess, J. R. (1978). Trophic relationships among fishes and plankton in the lagoon at Enewetak atoll, Marshall Islands. Fish. Bull. U.S. 76: 133-153

Johannes, R. E. (1967). Ecology of organic aggregates in the vicinity of a coral reef. Limnol. Oceanogr. 12: 189-195

Johannes, R. E. (1978). Reproductive strategies of coastal marine fishes in the tropics. Environ. Biol. Fish. 3: 65-84

Johannes, R. E., Gerber, R. P. (1974). Import and export of net plankton by an Eniwetok coral reef community. Proc. 2nd Int. Coral Reef Symp. 1: 97-104

Jones, R. S. (1968). Ecological relationships in Hawaiian and Johnston Island Acanthuridae (surgeonfishes). Micronesica 4: 309-361

Jones, R. S., Chase, J. A. (1975). Community structure and distribution of fishes in an enclosed high island lagoon in Guam. Micronesica 11: 127-148

Kikuchi, T., Peres, J. M. (1977). Consumer ecology of seagrass beds. In: McRoy, C. P., Hellferich, C. (eds.) Seagrass ecosystems: a scientific perspective. Marcel Dekker, New York, p. 147-193

Lal, P., Swamy, K., Singh, P. (1984). 'Mangrove ecosystem' fisheries associated with mangroves and their management. Mangrove fishes in Wairiki Creek and their implications on the management of resources in Fiji. In: Productivity and processes in island marine ecosystems. UNESCO Reports in Marine Science 27, p. 93-108

Leis, J. M. (1982). Distribution of fish larvae around Lizard Island, Great Barrier Reef: coral reef lagoon as refuge? Proc. 4th Int. Coral Reef Symp. 2: 471-477

Lobel, P. S., Ogden, J. C. (1981). Foraging by the herbivorous parrotfish Sparisoma radians. Mar. Biol. 64: 173-183

Lobel, P. S., Robinson, A. R. (1986). Transport and entrapment of fish larvae by ocean mesoscale eddies and currents in Hawaiian waters. Deep Sea Res. 33: 483-500

Main, K. L. (1987). Predator avoidance in seagrass meadows: Prey behavior, microhabitat selection, and cryptic coloration. Ecology 68: 170-180

Mann, K. H. (1969). The dynamics of aquatic ecosystems. Adv. Ecol Res. 6: 1-81

Marshall, N. (1985). Ecological sustainable yield (fisheries potential) of coral reef areas, as related to physiographic features of coral reef environments. Proc. 5th Int. Coral Reef Congr. 5: 525-530

Martin, F. D., Cooper, M. (1981). A comparison of fish faunas found in pure stands of two tropical Atlantic seagrasses, Thalassia testudinum and Syringodium filiforme. Northeast Gulf Sci. 5: 31-37

McFarland, W. N. (1979). Observations on recruitment in haemulid fishes. Proc. Gulf Caribb. Fish. Inst. 32: 132-138
McRoy, C. P., McMillan, C. (1977). Production ecology and physiology of seagrasses. In: McRoy, C. P., Hellferich, C (eds.) Seagrass ecosystems: a scientific perspective. Marcel Dekker, New York, p. 53-87

Meyer, J. L., Schultz, E. T., Helfman, G. S. (1983). Fish schools: an asset to corals. Science 220: 1047-1049

Munro, J. L. (1984). Coral reef fisheries and world fish production. ICLARM Newsletter 7: 3-4

Munro, J. L., Williams, D. M. (1985). Assessment and management of coral reef fisheries: biological, environmental and socioeconomic aspects. Proc. 5th Int. Coral Reef Congr. 4: 543-578

Nelson, S. G. (1985). Immediate enhancement of photosynthesis by coral reef macrophytes in response to ammonia enrichment. Proc. 5th Int. Coral Reef Congr. 5: 65-70

Neudecker, S. (1977). Transplant experiments to test the effect of fish grazing on coral distribution. Proc. 3rd Int. Coral Reef Symp. 1: 317-323

Neudecker, S. (1985). Foraging patterns of chaetodontid and pomacanthid fishes at St. Croix (U.S. Virgin Islands). Proc 5th Int. Coral Reef Congr. 5: 415-420

Norris, J. E. (1985). Trophic relationships of piscivorous coral reef fishes from the Northwestern Hawaiian Islands. M. S. thesis, University Hawaii, Honolulu

Norris, J. E., Parrish, J. D. (in press). Predator-prey relationships among fishes in pristine coral reef communities. Proc. 6th Int. Coral Reef Symp.

Odum, H. T., Burkholder, P. R., Rivero, J. (1959). Measurements of productivity of turtle grass flats, reefs, and the Bahia Fosforescente of southern Puerto Rico. Publs Inst. Mar. Sci. Univ. Tex. 6: 159-170

Odum, H. T., Odum, E. P. (1955). Trophic structure and productivity of a windward coral reef community on Eniwetok Atoll. Ecol. Monogr. 25: 291-320

Odum, W. E., Heald, E. J. (1972). Trophic analysis of an estuarine mangrove community. Bull. mar. Sci. 22: 671-738

Odum, W. E., Heald, E. J. (1975). The detritus-based food web of an estuarine mangrove community. In: Cronin, L. E. (ed.) Estuarine Research Vol. 1. Academic Press, New York, p. 265-286

Ogden, J. C. (1976). Some aspects of herbivore-plant relationships on Caribbean reefs and seagrass beds. Aquat. Bot. 2 103-116

Ogden, J. C. (1980). Faunal relationships in Caribbean seagrass beds. In: Phillips, R. C., McRoy, C. P. (eds.) Handbook of seagrass biology: an ecosystem perspective. Garland STPM Press, New York, p. 173-198

Ogden, J. C., Brown, R. A., Salesky, N. (1973). Grazing by the echinoid Diadema antillarum Philippi: formation of halos around West Indian patch reefs. Science 1.82: 715-717

Ogden, J. C., Gladfelter, E. H. (eds.) (1983). Coral reefs, seagrass beds and mangroves: their interaction in the coastal zones of the Caribbean. UNESCO Reports in Marine Science 23, p. 1-133

Ogden, J. C., Zieman, J. C. (1977). Ecological aspects of coral reef-seagrass bed contacts in the Caribbean. Proc. 3rd Int. Coral Reef Symp. 1: 377-382

O'Gower, A. K., Wacasey, J. J. (1967). Animal communities associated with Thalassia, Diplanthera and sand beds of Biscayne Bay. I. Analysis in relation to water movements. Bull. mar Sci. 17: 175-210

Ohlhorst, S. L. (1982). Diel migration patterns of demersal reef zooplankton. J. exp. mar Biol. Ecol. 60: 1-15

Parrish, J. D. (1987). Characteristics of fish communities on coral reefs and in potentially interacting shallow habitats in tropical oceans of the world. In: Birkeland, C. (ed.) 
Comparison between Atlantic and Pacific tropical marine coastal ecosystems: community structure, ecological processes, and productivity. UNESCO Reports in Marine Science 46, p. $171-218,47 a-47 \mathrm{C}$

Parrish, J. D., Callahan, M. W., Norris, J. E. (1985). Fish trophic relationships that structure reef communities. Proc. 5th Int. Coral Reef Congr. 4- 73-78

Parrish, J. D., Zimmerman, R. J. (1977). Utilization by fishes of space and food resources on an offshore Puerto Rican coral reef and its surroundings. Proc. 3rd Int. Coral Reef. Symp. 1: 297-303

Porter, J. W., Porter, K. G. (1977). Quantitative sampling of demersal plankton migrating from different coral reef substrates. Limnol. Oceanogr. 22: 553-556

Porter, J. W., Porter, K. G., Batac-Catalan, Z. (1977). Quantitative sampling of Indo-Pacific demersal reef plankton. Proc 3rd Int. Coral Reef Symp. 1- 106-112

Quinn, N. J., Kojis, B. J. (1985). Does the presence of coral reefs in proximity to a tropical estuary affect the estuarine fish assemblage? Proc. 5th Int. Coral Reef Congr. 5: $445-450$

Randall, J. E. (1963). An analysis of the fish populations of artificial and natural reefs in the Virgin Islands. Caribb. J. Sci. 3: $31-47$

Randall, J. E. (1965). Grazing effect on sea grasses by herbivorous reef fishes in the West Indies. Ecology 46: $255-260$

Randall, J. E. (1967). Food habits of reef fishes of the West Indies. Stud. Trop. Oceanogr (Miami) 5: 665-847

Randall, J. E. (1974). The effect of fishes on coral reefs. Proc. 2nd Int. Coral Reef Symp. 1-159-166

Randall, J. E.. Hartman, W D. (1968). Sponge-feeding fishes of the West Indies. Mar. Biol. 1: 216-225

Reese, E. S. (1977). Coevolution of corals and coral feeding fishes of the family Chaetodontidae. Proc. 3rd Int. Coral Reef Symp. 1: 267-274

Robertson, A. I., Alongi, D. M., Daniel, P. A., Boto, K. G. (In press). How much mangrove detritus enters the Great Barrier Reef lagoon? Proc. 6th Int. Coral Reef Symp.

Robertson, D. R. (1982). Fish feces as fish food on a Pacific coral reef. Mar. Ecol. Prog. Ser. 7: 253-265

Robertson, D. R., Polunin, N. V. C., Leighton, K. (1979). The behavioral ecology of three Indian Ocean surgeonfishes (Acanthurus lineatus, A. leucosternon, and Zebrasoma scopas): their feeding strategies, and social and mating systems. Environ. Biol. Fish. 4: 125-170

Rodelli, M. R., Gearing, J. N., Gearing, P. J., Marshall, N. Sasekumar, A. (1984). Stable isotope ratio as a tracer of mangrove carbon in Malaysian ecosystems. Oecologia (Berl.) 61: 326-333

Rodriguez, G. (1959). The marine communities of Margarita Island, Venezuela. Bull. mar. Sci. 9: 237-280

Russ, G. (1984a). Distribution and abundance of herbivorous grazing fishes in the central Great Barrier Reef. I. Levels of variability across the entire continental shelf. Mar. Ecol. Prog. Ser. 20: 23-34

Russ, G. (1984b). Effects of fishing and protective management on coral reefs at four locations in the Visayas, Philippines (Phase II). Project report UNEP-NRMC Coral Reef Monitoring, p. 1-54

Russ, G. (1985). Effects of protective management on coral reef fishes in the central Philippines. Proc. 5th Int Coral Reef Congr. 4: 219-224

Russell, B. C., Anderson, G. R. V., Talbot, F. H. (1977). Seasonality and recruitment of coral reef fishes. Aust. J. mar. Freshwat. Res. 28: 521-528

Rutzler, K. (1969). The mangrove community, aspects of its structure, faunistics and ecology. In: Ayala-Castanares, A. Phleger, F. B. (eds.) Coastal lagoons, a symposium. Memoir international symposium on coastal lagoons. UNAM-UNESCO, p. 515-535

Sale, P. F. (1980). The ecology of fishes on coral reefs Oceanogr. mar Biol. A. Rev. 18: 367-421

Sale, P. F. (1985). Patterns of recruitment in coral reef fishes Proc. 5th Int. Coral Reef Congr 5: 391-396

Sale, P. F., McWilliam, P. S., Anderson, D. T. (1976). Composition of the near-reef zooplankton at Heron Reef, Great Barrier Reef. Mar Biol. 34:59-66

Sammarco, P. W. (1985). The Great Barrier Reef vs, the Caribbean: comparisons of grazers, coral recruitment patterns and reef recovery. Proc. 5th Int. Coral Reef Congr. 4: 391-397

Sano, M. Shimizu, M., Nose, Y (1984). Food habits of teleostean reef fishes in Okinawa Island, southern Japan. The University Museum, University of Tokyo 25, p. 1-128

Sargent, M. C. Austin, T S. (1949). Organic productivity of an atoll. Trans. Am. geophys. Un. 30: 245-249

Schroeder, R. E. (1985). Recruitment rate patterns of coral-reef fishes at Midway lagoon (Northwestern Hawaiian Islands). Proc. 5th Int. Coral Reef Congr. 5: 379-384

Smith, C. L. (1978). Coral reef fish communities: a compromise view. Environ. Biol. Fish. 3: 109-128

Starck, W. A. II. (1968). A list of fishes of Alligator Reef, Florida with comments on the nature of the Florida reef fish fauna. Undersea Biol. 1: 5-40

Starck, W. A. II. (1971). Biology of the gray snapper, Lutjanus griseus (Linnaeus), in the Florida Keys. Stud. Trop. Oceanogr. (Miami) 10:1-150

Starck, W A. II, Davis, W. P. (1966). Night habits of fishes of Alligator Reef, Florida. Ichthyol. Aquar. J. 38: 313-356

Stephenson, W., Searles, R. B. (1960). Experimental studies on the ecology of intertidal environments at Heron Island. 1. Exclusion of fish from beach rock. Aust. J. mar. Freshwat. Res. 11. 241-267

Steven, D. M. (1961). Shoaling behavior in a mysid. Nature, Lond. 192: 280-281

Stimson, J., Blum, S., Brock, R. (1982). An experimental study of the influence of muraenid eels on reef fish sizes and abundance. Univ. Hawaii Sea Grant Quarterly 4, p. 1-6

Talbot, F. H. (1960). Notes on the biology of the Lutjanidae (Pisces) of the East African coast, with special reference to L. bohar (Forskal). Ann. S. Afr. Mus. 45: 549-573

Talbot, F. H. (1965). A description of the coral structure of Tutia Reef (Tanganyika Territory, East Africa), and its fish fauna. J. Zool., Lond. 145: 431-470

Talbot, F. H., Gilbert, A. J. (1982). A comparison of quantitative samples of coral reef fishes latitudinally and longitudinally in the Indo-West Pacific. Proc. 4th Int Coral Reef Symp. 2: 485-490

Taniguchi, A. (1972). Geographical variation of primary production in the western Pacific Ocean and adjacent seas with reference to the inter-relations between various parameters of primary production. Mem. Fac. Fish. Hokkaido Univ. 19: 1-33

Thomassin, B. A. (1974). Soft bottom carcinological fauna sensu lato on the Tulear coral reef complexes (S.W. Madagascar): distribution, importance, roles played in trophic food-chains and in bottom deposits. Proc. 2nd Int. Coral Reef Symp. 1: $297-320$

Tranter, D. J., George, J. (1972). Zooplankton abundance at Kavaratti and Kalpeni Atolls in the Laccadives. Proc. 1st Int. Coral Reef. Symp. 239-256

Tribble, G. W. (1981). Reef-based herbivores and the distribution of two seagrasses (Syringodium filiforme and Thalas- 
sia testudinum) in the San Blas Islands (Western Caribbean). Mar. Biol. 65: 277-281

Tundisi, J. (1969). Plankton studies in a mangrove environment - its biology and primary production. In: AyalaCastanares, A., Phleger, F. B. (eds.) Coastal lagoons, a symposium. Memoir international symposium on coastal lagoons. UNAM-UNESCO, p. 485-493

Vacelet, J., Vasseur, P. (1977). Sponge distribution in coral reefs and related areas in the vicinity of Tulear (Madagascar). Proc. 3rd Int. Coral Reef Symp. 1: 114-117

Vasseur, P. (1977). Cryptic sessile communities in various coral formations on reef flats in Tulear vicinity (Madagascar). Proc. 3rd Int. Coral Reef Symp. 1: 96-100

Victor, B. C. (1983). Recruitment and population dynamics of a coral reef fish. Science 219: 419-420

Vivien, M. L. (1973). Contribution à la connaissance de l'ethologie alimentaire de l'ichtyofaune de platier interne des récifs coralliens de Tuléar (Madagascar). Tethys Suppl. 5: 221-308

Vivien, M. L., Peyrot-Clausade, M. (1974). A comparative study of the feeding behaviour of three coral reef fishes (Holocentridae), with special. reference to the polychaetes of the reef cryptofauna as prey. Proc. 2nd Int. Coral Reef Symp. 1: 179-192

Wahbeh, M. I. (1982). Distribution, biomass, biometry and some associated fauna of the seagrass community in the Jordan Gulf of Aqaba. Proc. 4th Int. Coral Reef Symp. 2: $453-459$

Walker, B. W. (1960). The distribution and affinities of the

This review was presented by Dr $P$. W. Sammarco, Townsville, Australia marine fish fauna of the Gulf of California. Syst. Zool. 9: $123-133$

Walsh, W. J. (1987). Patterns of recruitment and spawning in Hawaiian reef fishes. Environ. Biol. Fish. 18: 257-276

Walter, C., Pasamonte, J. N., Talaue, L. (1982). A preliminary quantitative study on emergence of reef associated zooplankton from a Philippine coral reef. Proc. 4th Int. Coral Reef Symp. 1. 443-451

Weinstein, M. P., Heck, K. L., Jr (1979). Ichthyofauna of seagrass meadows along the Caribbean coast of Panama and in the Gulf of Mexico: composition, structure and community ecology. Mar. Biol. 50: 97-107

Weinstein, M. P., Heck, K. L., Jr., Giebel, P. E., Gates, J. E. (1982). The role of herbivory in pinfish (Lagodon rhomboides): a preliminary investigation. Bull. mar. Sci. 32: $791-795$

Williams, D. M. (1980). Dynamics of the pomacentrid community on small patch reets in One Tree Lagoon (Great Barrier Reef). Bull. mar. Sci. 30: 159-170

Williams, D. M. (1982). Patterns in the distribution of fish communities across the central Great Barrier Reef. Coral Reefs 1: $35-43$

Williams, D. M., Hatcher, A. I. (1983). Structure of fish communities on outer slopes of inshore, mid-shelf and outer shelf reefs of the Great Barrier Reef. Mar. Ecol. Prog. Ser 10: $239-250$

Winn, H. E., Bardach, J. E. (1960). Some aspects of the comparative biology of parrot fishes at Bermuda. Zoologica, N.Y 45: $29-34$

Manuscript first received: February 23, 1988

Revised version accepted: May 4, 1989 